\title{
Angiotensin-Converting Enzyme Inhibitors and Receptor Blockers Usage in COVID-19 Illness Leading to Confusion or Conclusion: a Comprehensive Review
}

\author{
Manasa Chandramouli ${ }^{1}$, Srikantamurthy Ningaiah ${ }^{1}$, Shridevi Doddamani ${ }^{2, *}$ \\ 1 Department of Chemistry, Vidyavardhaka College of Engineering, Visvesvaraya Technological University, Mysore-570 \\ 002, Karnataka, India \\ 2 Chemical Sciences and Technology Division, CSIR-NIIST, Thiruvananthapuram-695 019, Kerala, India \\ * Correspondence: shridevi20@gmail.com;
}

Received: 13.10.2020; Revised: 9.11.2020; Accepted: 12.11.2020; Published: 15.11.2020

\begin{abstract}
In the present situation, the consequence of the Angiotensin-Converting Enzyme inhibitors (ACEi) and Angiotensin Receptor Blockers (ARB) is being questioned since its usage has increased progressively due to its significance in the medical field as lifesaving drugs associated with cardiovascular diseases and renal failure. The novel study of these by researchers all around the world is showing varied opinions. Hence, the usage of the above-inhibitors in COVID-19 patients is reviewed, also discussing its pharmacological importance. This review is about the coronavirus's efficiency to develop in hosts who are in the regular treatment of ACEi and ARB. Besides, there is also a detailed mechanism of the coronavirus's attack on the host, which is reviewed. This gives a brief idea adopted for conventional approaches. It is also a detailed study of the ACEi/ARB in COVID-19 patients. It is believed this review particularly will help give a clear idea of ACEi/ARB in treating patients already suffering from the COVID-19 disease and help the further researchers in considering its use further for treating COVID-19 patients and to categorize it as a threat or not.
\end{abstract}

Keywords: SARS CoV2; ACEi; ARB; COVID-19.

(C) 2020 by the authors. This article is an open-access article distributed under the terms and conditions of the Creative Commons Attribution (CC BY) license (https://creativecommons.org/licenses/by/4.0/).

\section{Introduction}

Severe Acute Respiratory Syndrome Coronavirus-2 (SARS CoV-2) resulting in COVID-19, invading to the host cells by angiotensin-converting enzyme 2 (ACE2), bring about higher risks regarding cardiovascular diseases. It is noted that more than $7 \%$ of the infected host will suffer from myocardial injury critically [1]. Hence Angiotensin-Converting Enzyme2 inhibitors (ACE2i) and ARB have to be investigated further, despite ACE2 proven as the portal of infection. ACE2 is the regulator, a molecular receptor for the SARS CoV2 virus [2]. Moreover, this is the reason whether ACE2i administered patients are at higher risk of infections and, therefore, should be taken off the medication. We are fortunate enough to find some therapies under active working status for the prevention of COVID-19 and, thus, for its treatment.

Alongside, considerations to stress more on the importance of the infected patients' autopsy to ensure the ACE2 expression in both heart and lungs post the infection. As surveyed from a few reports, a 77 years old man autopsy revealed damage in alveolar tissues, persistent inflammation, and a 42-year-old man autopsy showed acute bronchopneumonia with evidence of aspiration [3]. Platelet fibrin thrombi in the arterial vessels are in harmony with 
coagulopathy. This has been important in COVID-19 patients and stressed for the main targets of therapy according to the interpretation from the autopsy study [4]. It is also studied that patients have known for their preexisting comorbidities with cardiovascular disease, most frequently, also show high risk associated with COIVD-19 [5].

It is possible to check ACEi and ARB's effect over the expression of ACE2 in the lungs by acute lung injury models in animals. Thus, it can ensure the probability of risk in infected patients who are clinically administered with ACEi and ARBs or any other cardiovascular drugs. Pulmonary inflammation severity can also be analyzed in these cases. ACE2 is on a protective role for both lung and cardiovascular injury. In contrast, for uninfected patients, we are still of the opinion that ACEi and ARBs should not be discontinued as there is no proof to hold up the hypothesis that SARS-CoV2 infection increases with the usage of ACEi and ARB. On an assertion, ACEi and ARBs protect patients from potential heart and lung injuries in COVID-19 as they can block the Renin-Angiotensin System (RAS). Now it is in no immediate call that the initiation of ACEi and ARBs be done as no evidence is claiming the continuity of life of COVID-19 patients. More clinical research and laboratory evidence are needed to prove the external addition of Recombinant Human Angiotensin-converting Enzyme-2 (rhACE2) to help combat and treat COVID-19 [6].

The liability of the infectious medical condition based on the emerging findings of COVID-19 has the quickest influence on clinical practice. The present knowledge to talk about the fiery issue is fragmented and not developed; this necessitates further research work and proper communications amongst the persons in the medical field and scientist in the said area.

\section{Chronicle}

In a stretch, the other zoonotic viruses that were witnessed in 2002-03, Severe Acute Respiratory Syndrome (SARS) epidemic, and Middle East Respiratory Syndrome (MERS$\mathrm{CoV}$ ) hold a high rate of fatality of $9.6 \%$ and $34.4 \%$, respectively. COVID-19 has proved itself the most fatal amongst the three, with a greater rate of infectivity and high-risk attack [7]. Past in the scene, the understanding of this novel virus, which is evolving as havoc at this stage, is only through the limited information in the literature, giving an idea of the early experience with COVID-19 and insights from the earlier illnesses of coronavirus, specifically MERS and SARS. SARS-CoV2 is due to a novel enveloped RNA $\beta$-coronavirus [8], an unsegmented, single-stranded, positive-sensed genome associated with the family; coronaviridae [9]. There are seven species of the former, which are known to cause infections in humans. Four are marked mainly for causing flulike symptoms and the rest three in causing potentially fatal illness. To name them, it is SARS, MERS, and presently COVID-19. It is in bats, which is believed to be the initial zoonotic host according to a working theory that several SARS-related coronaviruses has been discovered since its genome is in $96.2 \%$ match with that of bat coronavirus [10].

\section{Analytical and epidemic countenance}

The unfolding of the SARS-CoV2 has given out an unmatched provocation for the entire community of healthcare worldwide. High infectious rate, the ability of transmission through an asymptomatic phase, and comparatively low virulence have shown an accelerated transmission of this novel coronavirus afar the geographic restrictions, resulting in a pandemic. The very first case for this virus, popularly called coronavirus disease 2019 (COVID-19), 
showed up in Hubei, China, on 8 December, 2019 [7]. Thenceforward, just like a wink of an eye, say probably 3 months, this virus and its infections have spread out on a large scale in almost all the 177 countries across the world, with an approximate number of 12,929,306 cases being confirmed and 569,738 deaths (WHO statistics as on 14 July 2020 [11]. Similar to MERS and SARS, the primary target for COVID-19 is the respiratory tract. COVID-19, in many cases, has occurred as pneumonia [12], alongside or without both cardiogenic and distributive shock [13], to those patients with prior medications [14] are often vulnerable [15]. The cardiovascular system is also showing predicted involvement in many dissimilar modes. Assumingly below is the probable mechanism responsible for the cardiovascular impediment in COVID-19 [16].

Direct myocardial injury - ACE2 is an aminopeptidase enzyme highly exhibited in the heart [17] and lungs [18]. ACE2 has the main role in the cardiovascular system's neurohumoral regulation in both illness and normal health conditions. Thus, binding this SARS-CoV2 to the ACE receptor can lead to severe heart and lung injuries, changing its signaling pathways [19].

In continuation of the probe, ACE inhibitors are a set of medication that is administered to patients suffering from heart complaints, high blood pressure, and other conditions. It truly reduces the activity of the ACE, and hence the production of angiotensin II decreases. ACE inhibitors are usually seen in the list of medications for diabetes patients also. In this case, it is preventing the worsening of the kidney's condition that may lead to Renovascular disease [20].

In its association, there are also ARBs which interferes with the RAS. A natural substance is blocked in the body by ACE inhibitors, thus avoiding the angiotensin I getting converted to angiotensin II. While ARBs attack angiotensin's pathway by blocking angiotensin II from binding to the receptors on the blood vessels. During this pandemic time, the safety concern on the use of ACEi and ARB has gained attention since they cause upregulation in the expression of ACE II in many tissues, including cardiomyocytes [21].

\section{Host susceptibility, immunology, and pathogenesis}

ACE inhibited by ACEi results in lowered angiotensin I levels, which create a potential unfavorable observation wreath that finally results in raising the ACE2 receptors, which further correspond to the decreased angiotensin I substrate available and interact with the same. This increased level of ACE2 receptor leads to more sites of binding for SARS-CoV2 and favors the attack of COVID-19 infection. Particularly, it is seen evidently in hypertensive and/or diabetic people as they are often prescribed to take ACEi or ARB [22]. Backing this issue of interest, to date, there is no data to support it clinically, nor is there any evidence shown experimentally, but still, adverse effects are caused on discontinuation of these. Therefore, it is advised not to discontinue the ACEi/ ARB that is clinically prescribed [23], even if the patient develops COVID-19 [24].

The main reason for this topic is that SARS-CoV2 binds to ACE2 to achieve entry into human cells; there is a potential rise of the risk of contracting COVID-19 or developing the more severe disease in patients who are already on background treatment with ACEi/ARB. Many essential physiological functions are monitored by ACE2, a type I integral membrane protein [25]. Thus, it is expressed highly in the lungs' alveolar cells; it is also acting as the main portal for the entry of the virus to the (human) hosts [26].

At the same time, ACE2 portrays its vital part in the protection of the lungs. This virus binding to the receptor (ACE2) will deregulate the pathway for protecting the lungs, resulting in a condition of pathogenicity due to the virus [27]. By the receptor-mediated endocytosis, 
and following the binding to the ligand, the entry of SARS-CoV2 is similar to that of the Human Immunodeficiency Virus (HIV) [28].

Improper fixation of this disease maybe because it shows the asymptomatic mode of transmission in a large proportion[7]. There is a clue of inadequate capabilities in many regions leading to improper diagnosis and the difficulty in rebouncing between 2 to 3 weeks after infection. Seeing all this, it can be evidenced that SARS-CoV2 further gets complicated by asymptomatic dissemination, contributing to the spread of infection [29]. Even after several clinical trials, there has been no vaccine or any approved therapy for COVID-19 [30].

Expression of ACE2 at high levels is seen in the heart, lungs, macrophages, vascular endothelium, myocytes, and smooth muscles [31]. SARS-CoV and its infections are initiated by spike protein of the virus being attached to ACE2 [32]. ACE2 being a zinc metallopeptidase is involved in the cleavage mechanism of angiotensin.

In six studies (meta-analysis), including 1,527 patients with COVID-19 tested for the prevalence of Cardio Vascular Disease (CVD), it was noted with the ubiquity of hypertension, cerebrovascular, and cardiac disease. Diabetes to be $17.1 \%, 9.7 \%$, and $16.4 \%$ respectively [33]. Since it is easy to avail of the emerging international data results from multinational units [34], it can help inform the degree of risk for this disease with prior CVD [35].

\section{Transmission}

CVD mechanisms regulate the immunological functions [36], and other CVD risk factors like diabetes and hyperlipidemia, associating with it, and finally leading to a higher risk of the incident [37]. At present, CVD may be a marker indirectly relating to the COVID-19 prognosis. And since ACE2 is acting as a receptor for this virus, a better understanding of the mechanism outcomes between CVD and COVID-19 is necessary. Some data suggest that ACE and ARB increase the susceptibility to the virus [38].

In disparity, investigations have also exhibited that [39] ACEi or ARB may influence [40] the protective action of ACE2 to the lungs [41]. Currently, we are unclear about the therapeutic conclusions for ACEi or ARB for COVID-19. However, there is no sufficient data to correlate the ACEi or ARB contracting COVID-19 with fatality after infection [42]. The question of ACEi or ARB therapies for COVID-19 patients is also acknowledged by the European Society of Hypertension [43]. It is now a necessity to contribute more to the existing data [44] about the virus and a prescribed course [45] of medical treatment [46] to milieu the outbreak. It is useful to get potential mechanistic data if the relationship between the ACE2 protein, antihypertensive agent use, and COVID-19 prognosis is studied [47].

The two major classes of developing severe COVID-19 are one with CVD [48] and the other with diabetes [49], and ACE2 expression is increased in both cases. ACE2 also monitors and regulates the metabolic functions, involving blood pressure regulation and glycemia [50]. Yet the virus, SARS-CoV2 affecting the cardiovascular system by selecting ACE2, needs to be explored. However, the initial instances of COVID-19 have shown that there is an important effect of it on the heart and vessels, which can be examined by studying the cardiovascular system [51].

ACE2 is the sole receptor; after binding, the virus will get internalized through the endocytosis without reaching the intracellular chamber unless membrane fusion occurs [52].

SARS-CoV [53] and HCoV-NL63 [54] are known to have employed ACE2 as a receptor. Both SARS-CoV1 and 2 binds to cells through the same receptor ACE2 [55]. It is 
found that CoV has shown no binding to other receptors [56], namely, dipeptidyl peptidase-4 (DPP4) or aminopeptidase-N (APN) [57]. Knowing the functions of ACE2 in the cardiovascular system and its apparent relation to COVID-19 is the reason for the much importance that is given to ACE2 [58].

Many clinical societies have issued an accord on the use of ACEi or ARB in connection with the pandemic COVID-19 [59]. ACE2, being a transmembrane protein [60] with a singlepass [61] along with protease activity [62], can cleave the vasoconstrictor angiotensin II to vasodilator angiotensin 1-7 [63].

Therapies, which function as a counter-regulatory enzyme to the ACE1 functions, which synthesize ACE2, can also be tested [64]. Humans show a broad spectrum of protein expression found almost in the lung epithelium, the myocardium, the endothelium, the GI tract, bone marrow, kidney, spleen, and this forms evidence to the multi-organ damage that is observed as in SARS-CoV2 infection [65]. As observed in the epidemiology studies of COVID-19, ACE2 gene expression can also feature encoding on the ' $\mathrm{X}$ ' chromosome, leading to sex differences likely [66].

In animals, acute respiratory distress syndrome (ARDS), which usually occurs as a result of pneumonitis, induced chemically or through sepsis or by endotoxemia or by influenza, ACE2 has shown more lung injury [67] in comparison to its wild counterpart's histological studies [68] and by the ability to recoil inwards [69]. The phenotype of increasing ability to recoil inward was rescued by giving a rhACE2 [70], which confirms a link between ACE2 deficiency [71] and severe acute lung injury [72].

Losartan [73] rescinded influenza [74] in mice that were reported for the critical situation of the extreme injury in the lung. And as in humans, administering Losartan, an angiotensin II type-1 receptor (AT1R) blocker, curtail the worsening effect of the SARS-CoV spike protein in animal models of ARDS [75]. The above animal models were constitutive or inducible knockout systems. The virus transmitted initially from one species to another, utilizing ACE2 isoforms in swine, bats, civets, humans, with mutations, has now evolved as a novel pathogen [76]. The murine ACE2 is a non-functional receptor for SARS-CoV2. The study of this virus in mice requires a transgenic expression of the human ACE2 [77]. A soluble ACE2 in the bloodstream is introduced when the ACE2 gets cleaved by the membrane-bound protease ADAM17 [78]. Though this effect of ACE2 is unclear in humans [79], it has shown a favorable condition on lung infections in ARDS models and influenza infections [80].

Better clinical trials, on a large scale, are needed. However, soluble ACE2 is being studied in the phase II trial of ARDS [81]. Ongoing research is being carried out to determine whether the soluble ACE2 can be a specific therapeutic, as it is the trap for SARS-CoV2 [82]. On a note, the ACE2 enzyme shall not be hindered by ACE inhibitors though it shares some homology with ACE [83]. It is also noted that not in all animals, the ACEi or ARB exposure to ACE2 results in the upregulation of the ACE2 protein [84].

In the present situation, we have unclear evidence whether ACEi or ARB lessens or adds to the severity of the pandemic by SARS-CoV2 infections. Another mechanism in the hypothesis of virus causing direct injury to the myocardium by infections is mediated through vasculitis, as the ACE2 receptor is expressed highly in the veins of the artery and endothelial cells [85]. Clear evidence of SARS-CoV1 showing vasculitis with the lymphocyte and monocyte infiltration, vascular endothelial cell injury, and stromal edema in the heart is studied [86]. Vasculitis is a response of either direct entry of the virus into myocardial endothelial cells [87] or an indirect response in the immunology leading to hypersensitivity [88]. 
TMPRSS2 (Transmembrane Serine Protease 2), a host protease, which is membranebound and endosomal maturation is the actual necessities for the mechanism of exact membrane fusion, whereby a non-covalently bound interaction takes place between $S$ protein and ACE2, as a result of the fusion between viral and the endosomal membranes, giving access to the viral genome for replication [89].

Contradictory data regarding ACE1, ACE2, ARB activity levels at various tissues and it are finally resulting in the infection's susceptibility by SARS-CoV2, and its effects are also present [90]. Though trials are progressing in Losartan therapy on COVID-19, the total available data is insufficient to cease ACEi or ARB usage. It is also strongly recommended to continue, as they are life-prolonging therapies, and their withdrawal can indicate the risk of infection and consequent complications [91]. In the British Medical Journal, it is published that ACE2 levels increase by 5-fold with Lisinopril and by 3-fold with Losartan based on Ferrario et al. findings [92]. The susceptibility to SARS-CoV-2 is highly correspondent of the ACE2 expression. Therefore intake of ACEi/ ARB may lead to the SARS CoV2 infection in patients [93]. Due to this potential risk increasing in patients clinically administered with ACEi and ARBs, some cardiologists recommend their discontinuation [94]. Moreover, it is seen that the serum level of angiotensin II has increased in COVID19 patients and has a linear plot of the viral load against the lung injury; thus, the intake of ACEi and ARB may relieve lung injury and further might decrease heart and renal damage [95].

The above situations have put the cardiologists in a dilemma regarding ACEi and ARBs being discontinued. There is evidence for the prevention of heart failure phenotype due to overexpression of ACE2, whereas ACE2 deficiency can increase the heart failure rate. There is no direct evidence for the relation of ACE2 and SARS-CoV2 [96].

It is argued by some of the investigators that; use of ACEi or ARB may help prevent COVID-19 infection. Li et al. [97] observed the stimulation of negative feedback due to ACE inhibitors of ACE results in decreased pulmonary inflammation because of the lack of angiotensin II and upregulation of ACE2. Whereas Sun et al. [98], has resisted that the usage of ACEi impairs the two receptor pathways; ACE/angiotensin II/I and ACE2/angiotensin 17/MAS. This disruption in the pathways, mainly the ACE2/angiotensin 1-7/MAS could lead to fewer chances of SARS-CoV2 entering the cell due to less production of ACE2. From one of the vasoconstriction mechanisms, studies on some RAS inactivated animal models; it is observed that there is a relief from the symptoms of respiratory failure and severe pneumonia infers that the inhibitors of RAS may prove to be an excellent option in the treatment of COVID-19 pneumonia [99].

Indecisive investigations of Olmesartan, an ARB drug on the upregulation of ACE2, which in-turn influenced an excess secretion of urinary ACE2, was observed [100]. Though there is an upregulation of ACE2, their effects of fewer death rates are not yet explained convincingly. The pathway for protecting the lung is impaired since the ACE2 expressed in the lung has bound to the virus, resulting in viral infection.

\section{Conclusions}

The pathways that regulate the immune mechanisms are also interconnected to the mechanisms that result in CVD. The need of the hour research to confirm the use of ACEi and ARB in people infected with COVID-19. Many cardiology associations HFSA/ACC/AHA and ESC Hypertension Council) consented to the use of ACEi and ARB in COVID-19 patients in contradiction to the hype in social media, many heart complications, and the disease's 
evolution. People who have already prescribed this class of medications are suggested to continue their treatment with ACEi/ARB. WHO has also evidenced that there is a high risk of low outcomes of COVID-19 in patients who are already in the usage of ACEi/ ARB for a lifetime.

In summary, a disbalance in the ACE2 can contribute to ARDS, acute lung failure, CVD, and others. Enhancing ACE2 is also considered a valuable strategy. There is no proof of discontinuing ACEi and ARB that adds to profit since they are lifesaving, and stopping them can potentially be harmful. With all the literature on this concern, it can be ended like; the ACE2 is just a controversy in coronavirus infection. The presence of co-factors along with ACE2, should also be considered for the coronavirus infection [101].

\section{Funding}

This research received no external funding.

\section{Acknowledgments}

The authors are grateful to the CSIR-National Institute for Interdisciplinary Science and Technology (NIIST), Thiruvananthapuram, and the Management, Vidyavardhaka College of Engineering, Mysuru, for providing the necessary facility to carry out the research work.

\section{Conflicts of Interest}

The authors declare no conflict of interest.

\section{References}

1. Awadhesh, K.S.; Ritesh, G.; Anoop, M. Comorbidities in COVID-19: Outcomes in hypertensive cohort and controversies with renin angiotensin system blockers. Diabetes Metab Syndr. 2020, 14, 283-287, https://doi.org/10.1016/j.dsx.2020.03.016.

2. Gheblawi, M.; Wang, K.; Viveiros, A.; Nguyen, Q.; Zhong, J.-C.; Turner Anthony, J.; Raizada Mohan, K.; Grant Maria, B.; Oudit Gavin, Y. Angiotensin-Converting Enzyme 2: SARS-CoV-2 Receptor and Regulator of the Renin-Angiotensin System. Circulation Research 2020, 126, 1456-1474, https://doi.org/10.1161/circresaha.120.317015.

3. Barton, L.M.; Eric, J.D.; Edana, S.; Subha, G.; Sanjay, M. Covid-19 autopsies, oklahoma, USA. Am. J. Clin. Pathol. 2020, 153, 725-733, https://doi.org/10.1093/ajcp/aqaa062.

4. Carsana, L.; Sonzogni, A.; Nasr, A.; Rossi, R.S.; Pellegrinelli, A.; Zerbi, P.; Rech, R.; Colombo, R.; Antinori, S.; Corbellino, M.; Galli, M.; Catena, E.; Tosoni, A.; Gianatti, A.; Nebuloni, M. Pulmonary post-mortem findings in a series of COVID-19 cases from northern Italy: a two-centre descriptive study. The Lancet Infectious Diseases 2020, 20, 1135-1140, https://doi.org/10.1016/S1473-3099(20)30434-5.

5. Mahajan, K.; Chandra, K.S. Cardiovascular comorbidities and complications associated with coronavirus disease 2019. Medical Journal Armed Forces India 2020, 76, 253-260, https://doi.org/10.1016/j.mjafi.2020.05.004.

6. Guo, J.; Zheng, H.; Li, L.; Jiagao, L. Coronavirus disease 2019 (covid-19) and cardiovascular disease: a viewpoint on the potential influence of angiotensin-converting enzyme inhibitors/angiotensin receptor blockers on onset and severity of severe acute respiratory syndrome coronavirus 2 infection. J. Am. Heart Assoc. 2020, 9, https://doi.org/10.1161/JAHA.120.016219.

7. Wu, Z.; Jennifer, M.M. Characteristics of and important lessons from the coronavirus disease 2019 (COVID19) outbreak in China: summary of a report of 72314 cases from the Chinese Center for Disease Control and Prevention. JAMA 2020, 323, 1239-1242, https://doi.org/10.1001/jama.2020.2648.

8. Su, S.; Wong, G.; Shi, W.; Liu, J.; Lai, A.C.K.; Zhou, J.; Liu, W.; Bi, Y.; Gao, G.F. Epidemiology, genetic recombination, and pathogenesis of coronaviruses. Trends Microbiol. 2016, 24, 490-502, https://doi.org/10.1016/j.tim.2016.03.003.

9. Huang, C.; Wang, Y.; Li, X.; Ren, L.; Zhao, J.; Hu, Y.; Zhang, L.; Fan, G.; Xu, J.; Gu, X.; Cheng, Z.; Yu, T.; Xia, J.; Wei, Y.; Wu, W.; Xie, X.; Yin, W.; Li, H.; Liu, M.; Xiao, Y.; Gao, H.; Guo, L.; Xie, J.; Wang, G.; Jiang, R.; Gao, Z.; Jin, Q.; Wang, J.; Cao, B. Clinical features of patients infected with 2019 novel 
coronavirus in Wuhan, China. The Lancet 2020, 395, 497-506, https://doi.org/10.1016/S01406736(20)30183-5.

10. Zhou, P.; Yang, X.-L.; Wang, X.-G.; Hu, B.; Zhang, L.; Zhang, W.; Si, H.-R.; Zhu, Y.; Li, B.; Huang, C.L.; Chen, H.-D.; Chen, J.; Luo, Y.; Guo, H.; Jiang, R.-D.; Liu, M.-Q.; Chen, Y.; Shen, X.-R.; Wang, X.; Zheng, X.-S.; Zhao, K.; Chen, Q.-J.; Deng, F.; Liu, L.-L.; Yan, B.; Zhan, F.-X.; Wang, Y.-Y.; Xiao, G.-F.; Shi, Z.-L. A pneumonia outbreak associated with a new coronavirus of probable bat origin. Nature 2020, 579, 270-273, https://doi.org/10.1038/s41586-020-2012-7.

11. WHO Coronavirus Disease (COVID-19) Dashboard. Available at; https://covid19.who.int/ [Accessed 14 July 2020].

12. Zhou, F.; Yu, T.; Du, R.; Fan, G.; Liu, Y.; Liu, Z.; Xiang, J.; Wang, Y.; Song, B.; Gu, X.; Guan, L.; Wei, Y.; Li, H.; Wu, X.; Xu, J.; Tu, S.; Zhang, Y.; Chen, H.; Cao, B. Clinical course and risk factors for mortality of adult inpatients with COVID-19 in Wuhan, China: a retrospective cohort study. The Lancet 2020, 395 , 1054-1062, https://doi.org/10.1016/S0140-6736(20)30566-3.

13. Murthy, S.; Gomersall, C.D.; Fowler, R.A. Care for Critically Ill Patients With COVID-19. JAMA 2020, 323, 1499-1500, https://doi.org/10.1001/jama.2020.3633.

14. Wang, D.; Hu, B.; Hu, C.; Zhu, F.; Liu, X.; Zhang, J.; Wang, B.; Xiang, H.; Cheng, Z.; Xiong, Y.; Zhao, Y.; Li, Y.; Wang, X.; Peng, Z. Clinical Characteristics of 138 Hospitalized Patients With 2019 Novel Coronavirus-Infected Pneumonia in Wuhan, China. JAMA 2020, 323, 1061-1069, https://doi.org/10.1001/jama.2020.1585.

15. Li, Juyi; Xiufang, W.; Jian, C.; Hongmei, Z.; Aiping, D. Association of renin-angiotensin system inhibitors with severity or risk of death in patients with hypertension hospitalized for coronavirus disease 2019 (COVID-19) infection in Wuhan, China. JAMA cardiology 2020, 5,825-830, 10.1001/jamacardio.2020.1624.

16. Xiong, T.-Y.; Redwood, S.; Prendergast, B.; Chen, M. Coronaviruses and the cardiovascular system: acute and long-term implications. European Heart Journal 2020, 41, 1798-1800, https://doi.org/10.1093/eurheartj/ehaa231.

17. Oudit, G.Y.; Penninger, J.M. Recombinant Human Angiotensin-Converting Enzyme 2 as a New ReninAngiotensin System Peptidase for Heart Failure Therapy. Current Heart Failure Reports 2011, 8, 176-183, https://doi.org/10.1007/s11897-011-0063-7.

18. Harmer, D.; Maureen, G.; Richard, B.; Kenneth, L.C. Quantitative mRNA expression profiling of ACE 2, a novel homologue of angiotensin converting enzyme. FEBS letters 2002, 532, 107-110, 10.1016/s00145793(02)03640-2

19. Battagello, D. S.; Guilherme, D.; Marianne, O. K.; Ana, L. P. A.; Fernando, J. V.; Ricardo, G. C. Unpuzzling COVID-19: tissue-related signaling pathways associated with SARS-CoV-2 infection and transmission. Clinical Science 2020, 16, 2137-2160, https://doi.org/10.1042/CS20200904.

20. Mc Farlane, S.I; Ashok, K.; James, R.S. Mechanisms by which angiotensin-converting enzyme inhibitors prevent diabetes and cardiovascular disease. Am J Cardiol. 2003, 91, 30-37, https://doi.org/10.1016/S00029149(03)00432-6.

21. Ferrario Carlos, M.; Jessup, J.; Chappell Mark, C.; Averill David, B.; Brosnihan, K.B.; Tallant, E.A.; Diz Debra, I.; Gallagher Patricia, E. Effect of Angiotensin-Converting Enzyme Inhibition and Angiotensin II Receptor Blockers on Cardiac Angiotensin-Converting Enzyme 2. Circulation 2005, 111, 2605-2610, https://doi.org/10.1161/circulationaha.104.510461.

22. Fang, L.; Karakiulakis, G.; Roth, M. Are patients with hypertension and diabetes mellitus at increased risk for COVID-19 infection? The Lancet Respiratory Medicine 2020, 8, https://doi.org/10.1016/S22132600(20)30116-8.

23. de Simone, G. Position statement of the ESC Council on Hypertension on ACE-inhibitors and angiotensin receptor blockers. Eur Soc Cardiol 2020, https://www.escardio.org/Councils/Council-on-Hypertension(CHT)/News/position-statement-of-the-esc-council-on-hypertension-on-ace-inhibitors-andang\#: :text=The $\% 20$ Council $\% 20$ on $\% 20$ Hypertension $\% 20$ strongly,of\%20the $\% 20$ Covid $\% 2$ D $19 \% 20$ infecti on.

24. Bozkurt, B.; Kovacs, R.; Harrington, B. HFSA/ACC/AHA statement addresses concerns re: using RAAS antagonists in COVID-19. Latest in Cardiology [ACC news story] 2020.

25. Zhou, P.; Yang, X.-L.; Wang, X.-G.; Hu, B.; Zhang, L.; Zhang, W.; Si, H.-R.; Zhu, Y.; Li, B.; Huang, C.L.; Chen, H.-D.; Chen, J.; Luo, Y.; Guo, H.; Jiang, R.-D.; Liu, M.-Q.; Chen, Y.; Shen, X.-R.; Wang, X.; Zheng, X.-S.; Zhao, K.; Chen, Q.-J.; Deng, F.; Liu, L.-L.; Yan, B.; Zhan, F.-X.; Wang, Y.-Y.; Xiao, G.-F.; Shi, Z.-L. A pneumonia outbreak associated with a new coronavirus of probable bat origin. Nature 2020, 579, 270-273, https://doi.org/10.1038/s41586-020-2012-7.

26. Ge, X.-Y.; Li, J.-L.; Yang, X.-L.; Chmura, A.A.; Zhu, G.; Epstein, J.H.; Mazet, J.K.; Hu, B.; Zhang, W.; Peng, C.; Zhang, Y.-J.; Luo, C.-M.; Tan, B.; Wang, N.; Zhu, Y.; Crameri, G.; Zhang, S.-Y.; Wang, L.-F.; Daszak, P.; Shi, Z.-L. Isolation and characterization of a bat SARS-like coronavirus that uses the ACE2 receptor. Nature 2013, 503, 535-538, https://doi.org/10.1038/nature12711. 
27. Zhang, H.; Josef, M.P.; Yimin, L.; Nanshan, Z.; Arthur, S.S. Angiotensin-converting enzyme 2 (ACE2) as a SARS-CoV-2 receptor: molecular mechanisms and potential therapeutic target. Intensive Care Med. 2020, 46, 586-590, https://doi.org/10.1007/s00134-020-05985-9.

28. Wang, H.; Yang, P.; Liu, K.; Guo, F.; Zhang, Y.; Zhang, G.; Jiang, C. SARS coronavirus entry into host cells through a novel clathrin- and caveolae-independent endocytic pathway. Cell Research 2008, 18, 290301, https://doi.org/10.1038/cr.2008.15.

29. Mizumoto, K.; Kagaya, K.; Zarebski, A.; Chowell, G. Estimating the asymptomatic proportion of coronavirus disease 2019 (COVID-19) cases on board the Diamond Princess cruise ship, Yokohama, Japan, 2020. Euro Surveill 2020, 25, https://doi.org/10.2807/1560-7917.ES.2020.25.10.2000180.

30. Chen, W.-H.; Strych, U.; Hotez, P.J.; Bottazzi, M.E. The SARS-CoV-2 Vaccine Pipeline: an Overview. Current Tropical Medicine Reports 2020, 7, 61-64, https://doi.org/10.1007/s40475-020-00201-6.

31. Burrell, L.M.; Risvanis, J.; Kubota, E.; Dean, R.G.; MacDonald, P.S.; Lu, S.; Tikellis, C.; Grant, S.L.; Lew, R.A.; Smith, A.I.; Cooper, M.E.; Johnston, C.I. Myocardial infarction increases ACE2 expression in rat and humans. European Heart Journal 2005, 26, 369-375, https://doi.org/10.1093/eurheartj/ehi114.

32. Hoffmann, M.; Kleine-Weber, H.; Schroeder, S.; Krüger, N.; Herrler, T.; Erichsen, S.; Schiergens, T.S.; Herrler, G.; Wu, N.-H.; Nitsche, A.; Müller, M.A.; Drosten, C.; Pöhlmann, S. SARS-CoV-2 Cell Entry Depends on ACE2 and TMPRSS2 and Is Blocked by a Clinically Proven Protease Inhibitor. Cell 2020, 181, 271-280, https://doi.org/10.1016/j.cell.2020.02.052.

33. Li, B.; Yang, J.; Zhao, F.; Zhi, L.; Wang, X.; Liu, L.; Bi, Z.; Zhao, Y. Prevalence and impact of cardiovascular metabolic diseases on COVID-19 in China. Clinical Research in Cardiology 2020, 109, 531538, https://doi.org/10.1007/s00392-020-01626-9.

34. Zidar, D.A.; Al-Kindi, S.G.; Liu, Y.; Krieger, N.I.; Perzynski, A.T.; Osnard, M.; Nmai, C.; Anthony, D.D.; Lederman, M.M.; Freeman, M.L.; Bonomo, R.A.; Simon, D.I.; Dalton, J.E. Association of Lymphopenia With Risk of Mortality Among Adults in the US General Population. JAMA Network Open 2019, 2, e1916526-e1916526, https://doi.org/10.1001/jamanetworkopen.2019.16526.

35. Libby, P.; Paul, M.R.; Göran, K.H. Inflammation in atherosclerosis: from pathophysiology to practice. J Am Coll Cardiol. 2009, 54, 2129-2138, https://doi.org/10.1016/j.jacc.2009.09.009.

36. Fernández-Ruiz, I. Immune system and cardiovascular disease. Nat. Rev. Cardiol. 2016, 13, https://doi.org/10.1038/nrcardio.2016.127.

37. Saltiel, A.R.; Jerrold, M.O. Inflammatory mechanisms linking obesity and metabolic disease. J Clin Invest. 2017, 127, 1-4, https://doi.org/10.1172/JCI92035.

38. Zheng, Y.-Y.; Ma, Y.-T.; Zhang, J.-Y.; Xie, X. COVID-19 and the cardiovascular system. Nature Reviews Cardiology 2020, 17, 259-260, https://doi.org/10.1038/s41569-020-0360-5.

39. Gurwitz, D. Angiotensin receptor blockers as tentative SARS-CoV-2 therapeutics. Drug Development Research 2020, 81, 537-540, https://doi.org/10.1002/ddr.21656.

40. Ferrario Carlos, M.; Jessup, J.; Chappell Mark, C.; Averill David, B.; Brosnihan, K.B.; Tallant, E.A.; Diz Debra, I.; Gallagher Patricia, E. Effect of Angiotensin-Converting Enzyme Inhibition and Angiotensin II Receptor Blockers on Cardiac Angiotensin-Converting Enzyme 2. Circulation 2005, 111, 2605-2610, https://doi.org/10.1161/CIRCULATIONAHA.104.510461.

41. Imai, Y.; Kuba, K.; Rao, S.; Huan, Y.; Guo, F.; Guan, B.; Yang, P.; Sarao, R.; Wada, T.; Leong-Poi, H.; Crackower, M.A.; Fukamizu, A.; Hui, C.-C.; Hein, L.; Uhlig, S.; Slutsky, A.S.; Jiang, C.; Penninger, J.M. Angiotensin-converting enzyme 2 protects from severe acute lung failure. Nature 2005, 436, 112-116, https://doi.org/10.1038/nature03712.

42. Liu, R.; Ming, X.; Xu, O.; Zhou, J.; Peng, H.; Xiang, N.; Zhang, J.; Zhu, H. Association of Cardiovascular Manifestations with In-hospital Outcomes in Patients with COVID-19: A Hospital Staff Data. medRxiv 2020, https://doi.org/10.1101/2020.02.29.20029348.

43. de Simone, G. Position statement of the ESC Council on Hypertension on ACE-inhibitors and angiotensin receptor blockers. Eur Soc Cardiol 2020 https://www.escardio.org/Councils/Council-on-Hypertension(CHT)/News/position-statement-of-the-esc-council-on-hypertension-on-ace-inhibitors-and-ang

44. Driggin, E.; Madhavan, M.V.; Bikdeli, B.; Chuich, T.; Laracy, J.; Biondi-Zoccai, G.; Brown, T.S.; Der Nigoghossian, C.; Zidar, D.A.; Haythe, J.; Brodie, D.; Beckman, J.A.; Kirtane, A.J.; Stone, G.W.; Krumholz, H.M.; Parikh, S.A. Cardiovascular Considerations for Patients, Health Care Workers, and Health Systems During the COVID-19 Pandemic. Journal of the American College of Cardiology 2020, 75, 2352-2371, https://doi.org/10.1016/j.jacc.2020.03.031.

45. Canadian Cardiovascular Society. COVID-19 and concerns regarding use of ACEi/ARB/ARNi medications for heart failure or hypertension. https://www.ccs.ca/images/Images_2020/CCS_CHFS_statement_regarding_COVID_EN.pdf

46. World Health Organization. COVID-19 and the use of angiotensin-converting enzyme inhibitors and receptor blockers: scientific brief, 7 May 2020. No. WHO/2019-nCoV/Sci_Brief/ACE-I/2020.1. World Health Organization, 2020.

47. Snyder, E. M.; Bruce, D. J. ACE2 and COVID-19: using antihypertensive medications and pharmacogenetic considerations. Pharmacogenomics 21 2020, 10, 695, https://doi.org/10.2217/pgs-2020-0048 
48. Soro-Paavonen, A.; Gordin, D.; Forsblom, C.; Rosengard-Barlund, M.; Waden, J.; Thorn, L.; Sandholm, N.; Thomas, M.C.; Groop, P.H. Circulating ACE2 activity is increased in patients with type 1 diabetes and vascular complications. J Hypertens 2012, 30, 375-383. https://doi.org/10.1097/hjh.0b013e32834f04b6

49. Bindom, S.M.; Eric, L. The sweeter side of ACE2: physiological evidence for a role in diabetes. Mol Cell Endocrinol. 2009, 302, 193-202; https://doi.org/10.1016/j.mce.2008.09.020.

50. Jiang, F.; Yang, J.; Zhang, Y.; Dong, M.; Wang, S.; Zhang, Q.; Liu, F.F.; Zhang, K.; Zhang, C. Angiotensinconverting enzyme 2 and angiotensin 1-7: novel therapeutic targets. Nature Reviews Cardiology 2014, 11, 413-426, https://doi.org/10.1038/nrcardio.2014.59.

51. Hulot, J.-S. COVID-19 in patients with cardiovascular diseases. Archives of Cardiovascular Diseases 2020, 113, 225-226, https://doi.org/10.1016/j.acvd.2020.03.009.

52. Zhou, P.; Yang, X.-L.; Wang, X.-G.; Hu, B.; Zhang, L.; Zhang, W.; Si, H.-R.; Zhu, Y.; Li, B.; Huang, C.L.; Chen, H.-D.; Chen, J.; Luo, Y.; Guo, H.; Jiang, R.-D.; Liu, M.-Q.; Chen, Y.; Shen, X.-R.; Wang, X.; Zheng, X.-S.; Zhao, K.; Chen, Q.-J.; Deng, F.; Liu, L.-L.; Yan, B.; Zhan, F.-X.; Wang, Y.-Y.; Xiao, G.-F.; Shi, Z.-L. A pneumonia outbreak associated with a new coronavirus of probable bat origin. Nature 2020, 579, 270-273, https://doi.org/10.1038/s41586-020-2012-7.

53. Kuhn, J.H.; W. Li.; H. Choe.; Farzan, M. What's new in the renin-angiotensin system? Angiotensinconverting enzyme 2: a functional receptor for SARS coronavirus. Cell Mol Life Sci. 2004, 61, 2738-2743. https://doi.org/10.1007/s00018-004-4242-5.

54. Dijkman, R.; Jebbink, M.F.; Deijs, M.; Milewska, A.; Pyrc, K.; Buelow, E.; van der Bijl, A.; van der Hoek, L. Replication-dependent downregulation of cellular angiotensin-converting enzyme 2 protein expression by human coronavirus NL63. 2012, 93, 1924-1929, https://doi.org/10.1099/vir.0.043919-0.

55. Lim, H.; Ayoung, B.; Jongwan, K.; Min, S.K.; Jiaxin, L.; Ky-Youb, N.; et al. Hot Spot Profiles of SARSCoV-2 and Human ACE2 Receptor Protein-Protein Interaction Obtained by Density Functional TightBinding Fragment Molecular Orbital Method. NatureResearch 2020, https://doi.org/10.21203/rs.3.rs24570/v1.

56. Lan, J.; Ge, J.; Yu, J.; Shan, S.; Zhou, H.; Fan, S.; Zhang, Q.; Shi, X.; Wang, Q.; Zhang, L.; Wang, X. Structure of the SARS-CoV-2 spike receptor-binding domain bound to the ACE2 receptor. Nature 2020, 581, 215-220, https://doi.org/10.1038/s41586-020-2180-5.

57. Li, W.; Luo, R.; He, Q.; van Kuppeveld, F.J.M.; Rottier, P.J.M.; Bosch, B.-J. Aminopeptidase N is not required for porcine epidemic diarrhea virus cell entry. Virus Res 2017, 235, 6-13, https://doi.org/10.1016/j.virusres.2017.03.018.

58. Vaduganathan, M.; Vardeny, O.; Michel, T.; McMurray, J.J.V.; Pfeffer, M.A.; Solomon, S.D. ReninAngiotensin-Aldosterone System Inhibitors in Patients with Covid-19. 2020, 382, 1653-1659, https://doi.org/10.1056/NEJMsr2005760.

59. Atri, D.; Hasan, K.S.; Joshua, L.; Victor, N.; David, A.M.; Erin, A.B. COVID-19 for the cardiologist: a current review of the virology, clinical epidemiology, cardiac and other clinical manifestations and potential therapeutic strategies. JACC Basic Transl Sci. 2020, 5, 518-536, https://doi.org/10.1016/j.jacbts.2020.04.002.

60. Hamming, I.; Cooper, M.E.; Haagmans, B.L.; Hooper, N.M.; Korstanje, R.; Osterhaus, A.; Timens, W.; Turner, A.J.; Navis, G.; van Goor, H. The emerging role of ACE2 in physiology and disease. The Journal of Pathology 2007, 212, 1-11, https://doi.org/10.1002/path.2162.

61. Yousefi, R. The exogenous human recombinant ACE2 has therapeutic potential against covid-19. UNESCO/UNITWIN Interregional Network on "Biophysics, Biotechnology and Environmental Health control” SKYPE conference on 20 March, 2020 (1st Meeting). Under UNESCO Chair -Life Sciences (Biophysics, Biotechnology and Environmental Health).

62. Imai, Y.; Kuba, K.; Ohto-Nakanishi, T.; Penninger, J.M. Angiotensin-Converting Enzyme 2 (ACE2) in Disease Pathogenesis. Circulation Journal 2010, 74, 405-410, https://doi.org/10.1253/circj.CJ-10-0045.

63. Rice, G.I.; Daniel, A.T.; Peter, J.G.; Anthony, J.T.; Nigel, M.H. Evaluation of angiotensin-converting enzyme (ACE), its homologue ACE2 and neprilysin in angiotensin peptide metabolism. Biochem J. 2004, 383, 45-51, https://doi.org/10.1042/BJ20040634.

64. Ferrario, C.M.; Jasmina, V. The ANG-(1-7)/ACE2/mas axis in the regulation of nephron function. AM $J$ Physiol-Renal. 2010, 298, F1297-F1305, https://doi.org/10.1152/ajprenal.00110.2010.

65. Thierry, A.R.; Benoit, R. SARS-CoV2 may evade innate immune response, causing uncontrolled neutrophil extracellular traps formation and multi-organ failure. Clin Sci. 2020, 134, 1295-1300, https://doi.org/10.1042/CS20200531.

66. Wei, X.; Xiao, Y.-T.; Wang, J.; Chen, R.; Zhang, W.; Yang, Y.; Daojun, L.; Qin, C.; Gu, D.; Zhang, B.; Chen, W.; Hou, J.; Song, N.; Zeng, G.; Ren, S. Sex differences in severity and mortality among patients with COVID-19: evidence from pooled literature analysis and insights from integrated bioinformatic analysis. arXiv preprint arXiv:2003. 2020, arXiv:2003.13547

67. Imai, Y.; Kuba, K.; Rao, S.; Huan, Y.; Guo, F.; Guan, B.; Yang, P.; Sarao, R.; Wada, T.; Leong-Poi, H.; Crackower, M.A.; Fukamizu, A.; Hui, C.-C.; Hein, L.; Uhlig, S.; Slutsky, A.S.; Jiang, C.; Penninger, J.M. Angiotensin-converting enzyme 2 protects from severe acute lung failure. Nature 2005, 436, 112-116, https://doi.org/10.1038/nature03712. 
68. Yang, P.; Gu, H.; Zhao, Z.; Wang, W.; Cao, B.; Lai, C.; Yang, X.; Zhang, L.; Duan, Y.; Zhang, S.; Chen, W.; Zhen, W.; Cai, M.; Penninger, J.M.; Jiang, C.; Wang, X. Angiotensin-converting enzyme 2 (ACE2) mediates influenza H7N9 virus-induced acute lung injury. Scientific Reports 2014, 4, https://doi.org/10.1038/srep07027.

69. Zou, Z.; Yan, Y.; Shu, Y.; Gao, R.; Sun, Y.; Li, X.; Ju, X.; Liang, Z.; Liu, Q.; Zhao, Y.; Guo, F.; Bai, T.; Han, Z.; Zhu, J.; Zhou, H.; Huang, F.; Li, C.; Lu, H.; Li, N.; Li, D.; Jin, N.; Penninger, J.M.; Jiang, C. Angiotensin-converting enzyme 2 protects from lethal avian influenza A H5N1 infections. Nature Communications 2014, 5, 1-7, https://doi.org/10.1038/ncomms4594.

70. Pang, X.; Cui, Y.; Zhu, Y. Recombinant human ACE2: potential therapeutics of SARS-CoV-2 infection and its complication. Acta Pharmacologica Sinica 2020, 41, 1255-1257, https://doi.org/10.1038/s41401-0200430-6.

71. Verdecchia, P.; Cavallini, C.; Spanevello, A.; Angeli, F. The pivotal link between ACE2 deficiency and SARS-CoV-2 infection. European Journal of Internal Medicine 2020, 76, 14-20, https://doi.org/10.1016/j.ejim.2020.04.037.

72. Yan, T.; Rong, X.; Guoan, L. Angiotensin-converting enzyme 2 in severe acute respiratory syndrome coronavirus and SARS-CoV-2: A double-edged sword? FASEB J. 2020, 34, 6017-6026, https://doi.org/10.1096/fj.202000782.

73. de Andrade, J.R.; Melissa, G.A.V.; Meuris, G.C.; Shaobin, W. Oxidative degradation of pharmaceutical losartan potassium with N-doped hierarchical porous carbon and peroxymonosulfate. Chem. Eng. Trans. 2020, 382, https://doi.org/10.1016/j.cej.2019.122971.

74. Shen, L.; Mo, H.; Cai, L.; Kong, T.; Zheng, W.; Ye, J.; Qi, J.; Xiao, Z. Losartan prevents sepsis-induced acute lung injury and decreases activation of nuclear factor kappaB and mitogen-activated protein kinases. Shock (Augusta, Ga.) 2009, 31, 500-506. https://doi.org/10.1097/SHK.0b013e318189017a.

75. Sarzani, R.; Giulietti, F.; Di Pentima, C.; Filipponi, A.; Spannella, F. Antagonizing the renin-angiotensinaldosterone system in the era of COVID-19. Internal and Emergency Medicine 2020, 15, 885-887, https://doi.org/10.1007/s11739-020-02365-5.

76. Atri, D.; Siddiqi, H.K.; Lang, J.P.; Nauffal, V.; Morrow, D.A.; Bohula, E.A. COVID-19 for the Cardiologist: Basic Virology, Epidemiology, Cardiac Manifestations, and Potential Therapeutic Strategies. JACC: Basic to Translational Science 2020, 5, 518-536, https://doi.org/10.1016/j.jacbts.2020.04.002.

77. Lv, H.; Wu, N.C.; Mok, C.K.P. COVID-19 vaccines: Knowing the unknown. European journal of immunology 2020, 50, 939-943, https://doi.org/10.1002/eji.202048663.

78. Lambert, D.W.; Yarski, M.; Warner, F.J.; Thornhill, P.; Parkin, E.T.; Smith, A.I.; Hooper, N.M.; Turner, A.J. Tumor necrosis factor-alpha convertase (ADAM17) mediates regulated ectodomain shedding of the severe-acute respiratory syndrome-coronavirus (SARS-CoV) receptor, angiotensin-converting enzyme-2 (ACE2). J Biol Chem 2005, 280, 30113-30119, https://doi.org/10.1074/jbc.M505111200.

79. Heurich, A.; Hofmann-Winkler, H.; Gierer, S.; Liepold, T.; Jahn, O.; Pöhlmann, S. TMPRSS2 and ADAM17 Cleave ACE2 Differentially and Only Proteolysis by TMPRSS2 Augments Entry Driven by the Severe Acute Respiratory Syndrome Coronavirus Spike Protein. J Virol 2014, 88, 1293-1307, https://doi.org/10.1128/JVI.02202-13.

80. Ciaglia, E.; Vecchione, C.; Puca, A.A. COVID-19 Infection and Circulating ACE2 Levels: Protective Role in Women and Children. Front Pediatr. 2020, 8, https://doi.org/10.3389/fped.2020.00206.

81. Pang, X.; Cui, Y.; Zhu, Y. Recombinant human ACE2: potential therapeutics of SARS-CoV-2 infection and its complication. Acta Pharmacologica Sinica 2020, 41, 1255-1257,https://doi.org/10.1038/s41401-0200430-6.

82. Monteil, V.; Kwon, H.; Prado, P.; Hagelkrüys, A.; Wimmer, R.A.; Stahl, M.; Leopoldi, A.; Garreta, E.; Hurtado del Pozo, C.; Prosper, F.; Romero, J.P.; Wirnsberger, G.; Zhang, H.; Slutsky, A.S.; Conder, R.; Montserrat, N.; Mirazimi, A.; Penninger, J.M. Inhibition of SARS-CoV-2 Infections in Engineered Human Tissues Using Clinical-Grade Soluble Human ACE2. Cell 2020, 181, 905-913.e907, https://doi.org/10.1016/j.cell.2020.04.004.

83. Kai, H.; Kai, M. Interactions of coronaviruses with ACE2, angiotensin II, and RAS inhibitors-lessons from available evidence and insights into COVID-19. Hypertension Research 2020, 43, 648-654, https://doi.org/10.1038/s41440-020-0455-8.

84. Kow, C.S.; Zaidi, S.T.R.; Hasan, S.S. Cardiovascular Disease and Use of Renin-Angiotensin System Inhibitors in COVID-19. American Journal of Cardiovascular Drugs 2020, 20, 217-221, https://doi.org/10.1007/s40256-020-00406-0.

85. Hamming, I.; Timens, W.; Bulthuis, M.L.C.; Lely, A.T.; Navis, G.J.; van Goor, H. Tissue distribution of ACE2 protein, the functional receptor for SARS coronavirus. A first step in understanding SARS pathogenesis. The Journal of Pathology 2004, 203, 631-637, https://doi.org/10.1002/path.1570.

86. Cheng, V.C.C.; Susanna, K.P.L.; Patrick, C.Y.W.; Kwok, Y.Y. Severe acute respiratory syndrome coronavirus as an agent of emerging and reemerging infection. Clin Microbiol Rev. 2007, 20, 660-694. https://doi.org/10.1128/CMR.00023-07. 
87. Woudstra, L.; Juffermans, L.J.M.; van Rossum, A.C.; Niessen, H.W.M.; Krijnen, P.A.J. Infectious myocarditis: the role of the cardiac vasculature. Heart Failure Reviews 2018, 23, 583-595, https://doi.org/10.1007/s10741-018-9688-x.

88. Roncati, L.; Ligabue, G.; Fabbiani, L.; Malagoli, C.; Gallo, G.; Lusenti, B.; Nasillo, V.; Manenti, A.; Maiorana, A. Type 3 hypersensitivity in COVID-19 vasculitis. Clinical Immunology 2020, 217, https://doi.org/10.1016/j.clim.2020.108487.

89. Glowacka, I.; Bertram, S.; Herzog, P.; Pfefferle, S.; Steffen, I.; Muench, M.O.; Simmons, G.; Hofmann, H.; Kuri, T.; Weber, F.; Eichler, J.; Drosten, C.; Pöhlmann, S. Differential Downregulation of ACE2 by the Spike Proteins of Severe Acute Respiratory Syndrome Coronavirus and Human Coronavirus NL63. J Virol 2010, 84, 1198-1205, https://doi.org/10.1128/JVI.01248-09.

90. Wang, L.; Wang, Y.; Ye, D.; Liu, Q. Review of the 2019 novel coronavirus (SARS-CoV-2) based on current evidence. International Journal of Antimicrobial Agents 2020, 55, https://doi.org/10.1016/j.ijantimicag.2020.105948.

91. Roshanov, P.S.; Rochwerg, B.; Patel, A.; Salehian, O.; Duceppe, E.; Belley-Côté, E.P.; Guyatt, G.H.; Sessler, D.I.; Le Manach, Y.; Borges, F.K.; Tandon, V.; Worster, A.; Thompson, A.; Koshy, M.; Devereaux, B.; Spencer, F.A.; Sanders, R.D.; Sloan, E.N.; Morley, E.E.; Paul, J.; Raymer, K.E.; Punthakee, Z.; Devereaux, P.J. Withholding versus Continuing Angiotensin-converting Enzyme Inhibitors or Angiotensin II Receptor Blockers before Noncardiac Surgery: An Analysis of the Vascular events In noncardiac Surgery patIents cOhort evaluatioN Prospective Cohort. Anesthesiology 2017, 126, 16-27, https://doi.org/10.1097/ALN.0000000000001404.

92. Ferrario, C. M.; Jessup, J.; Chappell, M. C.; Averill, D.B.; Brosnihan, K.B.; Tallant, E.A.; Diz, D.I.; Gallagher, P.E. Effect of angiotensin-converting enzyme inhibition and angiotensin II receptor blockers on cardiac angiotensinconverting enzyme 2. Circulation 2005, 111, 2605-10. https://doi.org/10.1161/CIRCULATIONAHA.104.510461.

93. Speth, R.C. Keep taking your ACE inhibitors and ARBs during the COVID 19 pandemic. Journal of Travel Medicine 2020, 27, https://doi.org/10.1093/jtm/taaa045.

94. Lia, Y.; Cheng, X.; Zen, Q.; Chen, Z.; Wang, Z.; Yuan, J. Expert recommendations for management and treatment of cardiovascular diseases under the epidemic situation of novel coronavirus pneumonia in Hubei province. J Clin Cardiol. 2020, 36, 201-203, http://kns.cnki.net/kcms/detail/42.1130.R.20200 221.0950.001.html.( Accessed 22 March, 2020)

95. Liu, Y.; Yang, Y.; Zhang, C.; Huang, F.; Wang, F.; Yuan, J.; Wang, Z.; Li, J.; Li, J.; Feng, C.; Zhang, Z.; Wang, L.; Peng, L.; Chen, L.; Qin, Y.; Zhao, D.; Tan, S.; Yin, L.; Xu, J.; Zhou, C.; Jiang, C.; Liu, L. Clinical and biochemical indexes from $2019-\mathrm{nCoV}$ infected patients linked to viral loads and lung injury. Science China Life Sciences 2020, 63, 364-374, https://doi.org/10.1007/s11427-020-1643-8.

96. Groß, S.; Jahn, C.; Cushman, S.; Bär, C.; Thum, T. SARS-CoV-2 receptor ACE2-dependent implications on the cardiovascular system: From basic science to clinical implications. Journal of Molecular and Cellular Cardiology 2020, 144, 47-53, https://doi.org/10.1016/j.yjmcc.2020.04.031.

97. Schunkert, H.; Ingelfinger, J.R.; Hirsch, A.T.; Pinto, Y.; Remme, W.J.; Jacob, H.; Dzau, V.J. Feedback regulation of angiotensin converting enzyme activity and mRNA levels by angiotensin II. Circulation Research 1993, 72, 312-318, https://doi.org/10.1161/01.RES.72.2.312.

98. Rico-Mesa, J.S.; White, A.; Anderson, A.S. Outcomes in Patients with COVID-19 Infection Taking ACEI/ARB. Current Cardiology Reports 2020, 22, 1-4, https://doi.org/10.1007/s11886-020-01291-4.

99. Sun. M.L.; Yang, J.M.; Sun, Y.P.; Su, G.H. Inhibitors of RAS might be a good choice for the therapy of COVID-19 pneumonia. . Zhonghua jie he he hu xi za zhi= Zhonghua jiehe he huxi zazhi= Zhonghua Jie He he huxi zazhi. 2020, 43, https://doi.org/10.3760/cma.j.issn.1001-0939.2020.0014.

100. Furuhashi, M.; Moniwa, N.; Mita, T.; Fuseya, T.; Ishimura, S.; Ohno, K.; Shibata, S.; Tanaka, M.; Watanabe, Y.; Akasaka, H.; Ohnishi, H.; Yoshida, H.; Takizawa, H.; Saitoh, S.; Ura, N.; Shimamoto, K.; Miura, T. Urinary Angiotensin-Converting Enzyme 2 in Hypertensive Patients May Be Increased by Olmesartan, an Angiotensin II Receptor Blocker. American Journal of Hypertension 2015, 28, 15-21, https://doi.org/10.1093/ajh/hpu086.

101. Gu, J.; Christine, K. Pathology and pathogenesis of severe acute respiratory syndrome. Am. J. Clin. Pathol. 2007, 170, 1136-1147, https://doi.org/10.2353/ajpath.2007.061088. 